\title{
Hydrolink gels: a rapid and simple approach to the detection of DNA mutations in thromboembolic disease
}

\author{
D J Perry, R W Carrell
}

\begin{abstract}
Aims: To develop a simple and rapid technique for detecting DNA mutations based on the polymerase chain reaction, followed by electrophoresis, in a novel polymer-Hydrolink D5000-specifically designed to separate double stranded DNA fragments.

Methods: Eleven subjects with previously characterised mutations within the antithrombin gene (including single base pair mutations and insertions) and three normal controls were studied. DNA was amplified and one sixth of the PCR product electrophoresed in a $20 \mathrm{~cm} \times 20 \mathrm{~cm} \times 1 \mathrm{~mm} \mathrm{100 \%} \mathrm{Hydrolink}$ D5000 gel for two to six hours, followed by staining in ethidium bromide for 20 minutes. The gel was then visualised under ultraviolet light.

Results: After amplification and electrophoresis a single additional band was observed in five out of nine variants in which the mutations involved a single base pair substitution, while two additional bands were seen in four out of nine mutants which arose as a result of a single base pair insertion. No abnormality was detected in two known variants.

Conclusion: This method provides a simple and rapid approach to the screening and detection of mutations at the DNA level which does not involve the use of either toxic reagents or radioisotopes. It may also provide evidence about the type of mutation.
\end{abstract}

The rapid and efficient detection of DNA mutations has become increasingly important as our knowledge of the molecular basis of human disease increases. Directly identifying such mutations allows both accurate carrier detection and early antenatal diagnosis to be performed, thus eliminating many of the problems associated with the use of indirect methods, such as linkage or restriction fragment length polymerase analysis, while at the same time increasing our understanding of the molecular pathology of specific diseases. DNA mutations range from major deletions to changes of a single base, but in most diseases changes in a single base pair seem to predominate. Current techniques involve the painstaking sequencing of each of the individual coding units (exons) of the gene. Consequently the detection of a single basepair mutation involves several weeks of work and some form of screening technique is therefore desirable.

With the development of the polymerase chain reaction $(P C R)^{1}$ a method has become available which permits the rapid generation of relatively large amounts of DNA from a defined region of the genome without cloning. Based on the PCR technique, several methods (single chain conformation polymorphism (SSCP) analysis, ${ }^{2}$ denaturing gradient gel electrophoresis (DGGE), ${ }^{3}$ chemical cleavage of mismatches $(\mathrm{CCM})^{4}$ ) have been developed which permit screening for genetic mutations without recourse to sequencing. Such methods depend on the formation of mixed DNA double strands - heteroduplexes-in the final stage of the PCR. These heteroduplexes arise in heterozygotes in which $50 \%$ of the final PCR product will be normal DNA and $50 \%$ abnormal, assuming that both alleles are amplified with the same efficiency. By denaturing the final PCR product and allowing it to reanneal, there is a $50 \%$ chance that one normal strand and one strand carrying the mutant or variant nucleotide will combine, giving rise to the heteroduplex. Such heteroduplexes have been shown to have an abnormal migration pattern on electrophoresis. $^{5}$

The techniques available for detecting heteroduplex formation have disadvantages in that they tend to be complex or tedious to perform and involve the use of radioisotopes or toxic reagents; they are also limited in the size of the PCR fragment which can be analysed.

Recently, the development of a novel polymer specifically for separating double stranded DNA has been shown to be capable of detecting heteroduplexes formed in the PCR reaction. ${ }^{6}$ We have adapted this technique to screen for mutations in the amplified DNA and demonstrate its use in the identification of a series of variants of antithrombin (AT) found in patients with thromboembolic disease.

\section{Methods}

DNA samples from 11 subjects with previously characterised antithrombin variants involving exons 2-6 were used as positive controls. DNA samples from three normal, 
unrelated subjects were used as negative controls.

PCR AMPLIFICATION OF THE ANTITHROMBIN GENE

Synthetic oligonucleotide primers were designed to amplify selectively each of the seven exons of the antithrombin gene (including the intron-exon splice sites) and the promoter region. ${ }^{78}$ A $100 \mu$ l amplification reaction comprising 100 pmoles of each primer pair, $200 \mu \mathrm{M}$ final concentration of each dNTP, $1 \mu \mathrm{g}$ of genomic DNA, $10 \mu \mathrm{l}$ of $10 \times$ PCR buffer (100 mM TRIS-HCl, pH 8.3, $500 \mathrm{mM} \mathrm{KCl}$, $15 \mathrm{mM} \mathrm{MgCl}, 0.01 \% \mathrm{w} / \mathrm{v}$ gelatin) was performed for each DNA sample. Samples were denatured by boiling for five minutes, quickly centrifuged, and placed in a Thermal Cycler (Perkin Elmer Cetus, Beaconsfield, England) at the appropriate annealing temperature for each primer pair. Two units of "Taq" polymerase ("Amplitaq" Perkin Elmer Cetus) were added and the reaction overlaid with $100 \mu \mathrm{l}$ of light mineral oil. Thirty five cycles of amplification were performed, the optimal annealing temperatures and extension times for each primer pair having been established previously. After 35 cycles of amplification a final step consisting of denaturation at $94^{\circ} \mathrm{C}$ for 30 seconds, followed by annealing for 60 minutes at $70^{\circ} \mathrm{C}$, was included to encourage heteroduplex formation. Following amplification $10 \mu \mathrm{l}$ of the PCR product was run on a $1.5 \%$ agarose gel in $1 \times$ TRIS-borate-EDTA (TBE) to check the efficiency and specificity of amplication.

\section{HYDROLINK GEL ELECTROPHORESIS}

Gels $20 \mathrm{~cm} \times 20 \mathrm{~cm} \times 1 \mathrm{~mm}$ were cast using a gel mix comprising $5 \mathrm{ml} 10 \times$ TBE and $44.4 \mathrm{ml}$ Hydrolink gel mix (Type D-5000, Hoeffer Scientific, Newcastle) and polymerised

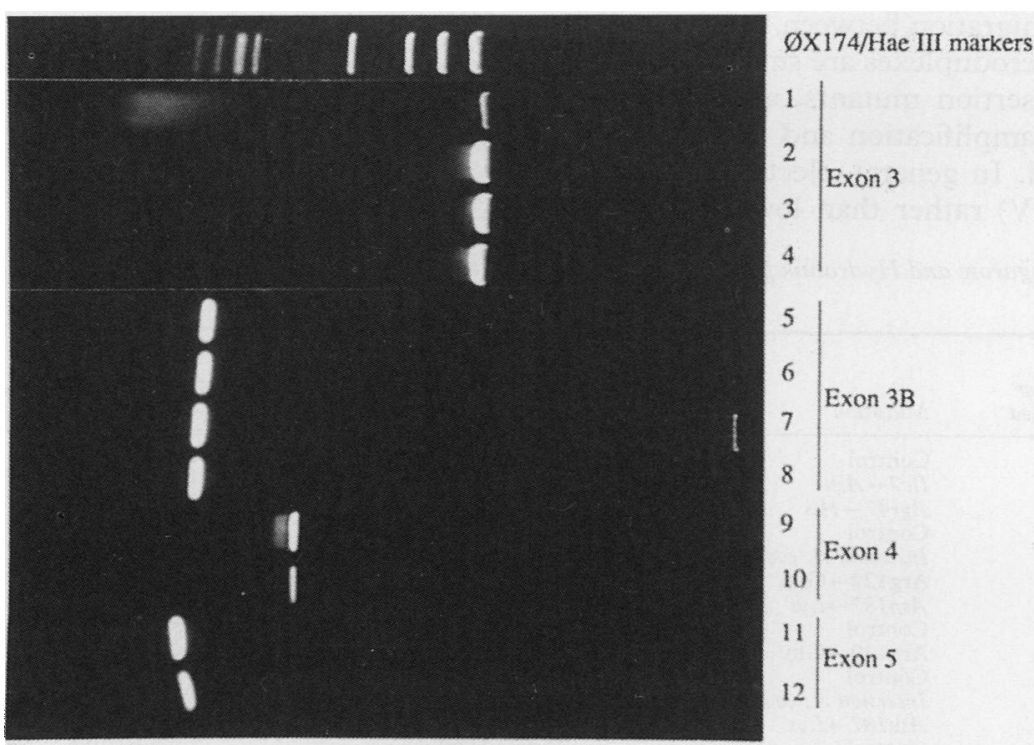

Figure $1 A 1 \cdot 5 \%$ agarose gel containing ethidium bromide $0.5 \mu \mathrm{g} / \mathrm{ml}$, showing the results of amplifying exons 3, 3B, 4 and 5. Lanes 1, 5, 9 and 11 are controls, the remaining lanes are characterised antithrombin variants. A single band is seen in each case. Lanes 1-4 contain identical samples to lanes $5-8$ but are amplified in a 1.4 base pair fragment rather than a 262 base pair fragment. using $35 \mu \mathrm{l}$ TEMED and $750 \mu \mathrm{l} 10 \%$ ammonium persulphate. A 20 -well comb with $0.5 \mathrm{~cm}$ diameter wells was used. The gel was pre-run at room temperature for 30 minutes in $1 \times$ TBE. PCR samples $(14-16 \mu l)$ were applied in loading buffer (sucrose $5 \%$, Orange$\mathrm{G} 0.06 \%$ ) and electrophoresed at $200 \mathrm{~V}$ until the Orange-G dye front reached the end of the gel-about two to three hours. Following electrophoresis the gel was soaked in $1 \times$ TBE containing ethidium bromide $(0.5 \mu \mathrm{g} / \mathrm{ml})$ and then photographed on an ultraviolet transilluminator.

\section{Results}

Of the 11 subjects with defined antithrombin mutations, agarose gel electrophoresis of the PCR product showed only a single band. Following Hydrolink gel electrophoresis five of 11 variants showed a single additional band that was absent in the controls, while four of 11 variants showed two additional bands, again not present in any of the controls. In five of nine variants in which an abnormal pattern was observed following Hydrolink gel electrophoresis the additional bands migrated slower than the control bands; in the remaining four variants the abnormal bands were reduced in intensity and also migrated faster.

Figs 1 and 2 show the results of agarose and Hydrolink gel electrophoresis of five antithrombin variants involving exons $3 B, 4$, and 5 . In each case agarose gel electrophoresis showed only a single band (fig 1). Exon 3 of the antithrombin gene consists of 2 exons ( $3 A$ and 3B) separated by a 780 base pair intron. When both exons and the intervening intron were amplified as a single 1.4 kilobase fragment, no abnormalities were visible on the Hydrolink gel (fig 2: lanes 2-4), but when exon 3B was amplified separately the additional bands were clearly visible (fig 2: lanes $6-8$ ). We have recently found that if the electrophoresis times for the 1.4 kilobase exon 3 amplification are increased to six hours then the heteroduplex bands become clearly visible. Hydrolink gel electrophoresis of the exon 4 variant (fig 2: lane 10) showed only a single band and represents one of two variants not identified by this technique. Electrophoresis of the exon 5 variant (fig 2 : lane 12) shows a clearly abnormal pattern with the presence of two separate bands in addition to the single band seen in the control.

These findings and the nature of the mutations are summarised in the table.

\section{Discussion}

We have evaluated a novel approach to the detection of DNA mutations after use of the PCR that is both simple and rapid to perform and does not involve the use of radioisotopes, toxic reagents, or complex equipment. Results are available within six to eight hours of DNA extraction compared with several days for techniques involving radioisotopes. The technique is capable of detecting heteroduplex formation arising from both single base pair mutations and insertions and is likely to detect 


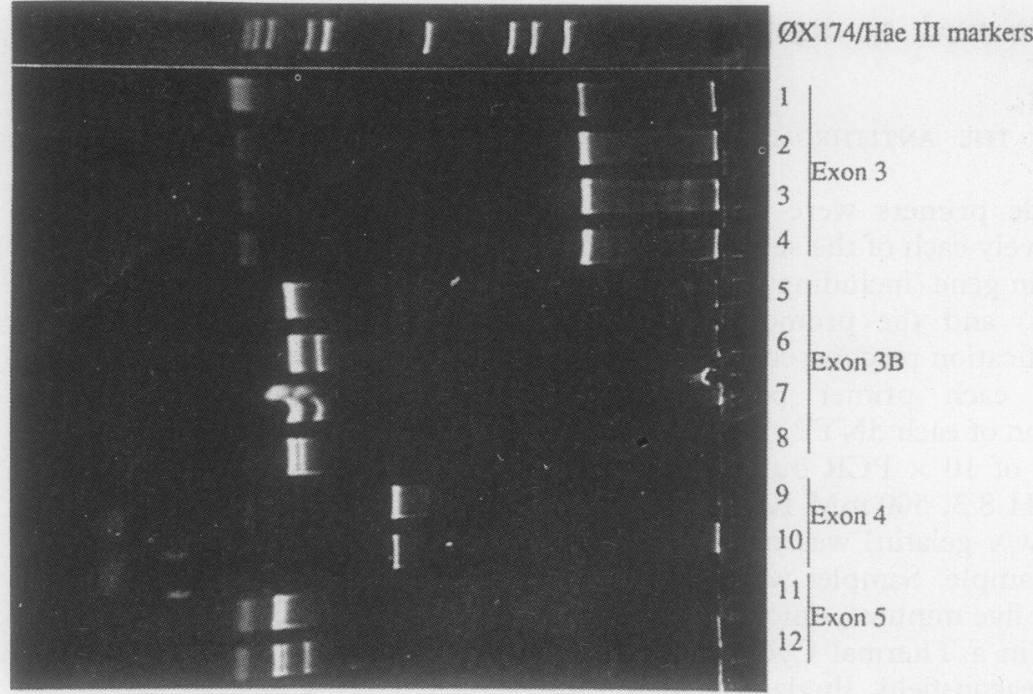

Figure 2 Identical to fig 1, but the amplified samples have been electrophoresed at $200 \mathrm{~V}$ for three hours in a $100 \%$ Hydrolink gel and then stained with ethidium bromide. A clearly abnormal pattern is seen in lanes $6,7,8$ and 12 which contain amplified DNA from known antithrombin variants, compared with the controls (lanes 1, 5,9 and 11). By extending the electrophoresis times for the exon 3 variants (lanes 2-4) to six hours, the mutations in these samples were clearly visible.

small deletions in a similar way. By increasing the electrophoresis times it can detect mutations in relatively large PCR fragments, facilitating rapid screening of genes.

The variation in the number of bands seen following Hydrolink gel electrophoresis reflects differences in the mobility of the heteroduplexes formed during the PCR, possibly as a result of changes in secondary structure. A single additional band was observed in those variants in which the mutation was a single base pair substitution, while two additional bands were seen in mutants which arose as a result of a single base pair insertion. The insertion type of mutation seems to generate heteroduplexes with altered mobility while the single base substitution produces heteroduplexes with identical mobilities. This technique may therefore indicate the type of mutation present.

It must be emphasised that in many cases the observed differences in migration between the normal band and the heteroduplexes are small especially in the non-insertion mutants, and the quality of both the amplification and the hydrolink gel are critical. In general, electrophoresis at higher $(200 \mathrm{~V})$ rather than lower voltages seems to increase resolution as does the use of sucrose in the loading buffer and the use of only a single tracker dye.

Two mutations were not detected using this technique - a single base pair mutation in exon 3A (Arg129 $\rightarrow$ Gln) and a single base pair mutation in exon 4 (Glu237 $\rightarrow$ Lys). It is not clear why these two mutations were not detected, although it may indicate a failure in heteroplex formation at the end of the PCR or that the heteroduplexes, although present, migrate at the same rate as the homoduplexes.

The use of Hydrolink gels for the screening of heteroduplex formation in PCRs offers a rapid and efficient means of detecting single base pair changes, although a negative result does not exclude a mutation. The identification of the affected exon decreases the amount of DNA which must be sequenced and reduces the sequencing time from the previous several weeks to three to four days. This technique should prove a valuable addition to the currently available methods for detecting not only DNA mutations but also polymorphisms in heterozygous subjects. We gratefully acknowledge the support of The Wellcome Trust,
The British Heart Foundation, the Medical Research Counci The British Heart Foundation, the Medical Research Council
and the many physicians who provided DNA samples for and the
analysis.

1 Saiki RK, Scharf S, Faloona F, Mullis KB, Horn GT, Erlich HA, Arnheim N. Enzymatic amplification of $\beta$-globin genomic sequences and restriction site analysis for diagnosis of sickle cell anaemia. Science 1985;230:1350-4.

2 Orita M, Suzuki Y, Sekiya T, Hayashi K. Rapid and sensitive detection of point mutations and DNA polymorphisms using the polymerase chain reaction. Genomics 1989;5:874-9.

3 Fischer SG, Lerman LS. DNA fragments differing by single base-pair substitutions are separated in denaturing gradient gels: Correspondence with melting theory. Proc Natl Acad Sci USA 1983;80:1579-83.

4 Cotton RGH, Rodrigues NR, Campbell RD. Reactivity of cytosine and thymine in single-base-pair mismatches with hydroxylamine and osmium tetroxide and its application to the study of mutations. Proc Natl Acad Sci USA 1988;85:4397-401.

5 Clay TM, Bidwell JL, Howard MR, Bradley BA. PCRfingerprinting for selection of HLA matched unrelated marrow donors. Lancet 1991;337:1049-52.

6 Keen J, Lester D, Inglehearn C, Curtis A, Bhattacharya S. Rapid detection of single-base mismatches as heteroduplexes on Hydrolink gels. Trends in Genetics 1991;7:5.

7 Prowchownik EV, Bock SC, Orkin SH. Intron structure of the human antithrombin III gene differs from that of other members of the serine protease inhibitor superfamily. $J$ Biol Chem 1985;260:9608-12.

8 Bock SC, Marrinan JA, Radziejewska E. Antithrombin III Utah: Proline-407 to leucine mutation in a highly conserved region near the inhibitor reactive site. Biochemistry 1988;27:6171-8.

Summary of results following agarose and Hydrolink gel electrophoresis of 11 antithrombin variants and three normal controls

\begin{tabular}{|c|c|c|c|c|c|}
\hline \multirow[b]{2}{*}{ Exon } & \multirow{2}{*}{$\begin{array}{l}\text { Fragment } \\
\text { size } \\
\text { (base pair) }\end{array}$} & \multirow{2}{*}{$\begin{array}{l}\text { Number } \\
\text { analysed }\end{array}$} & \multirow[b]{2}{*}{ Mutation } & \multicolumn{2}{|c|}{ Results of electrophoresis in: } \\
\hline & & & & Agarose & Hydrolink \\
\hline 2 & 527 & $\begin{array}{l}2 \\
1 \\
1\end{array}$ & $\begin{array}{l}\text { Control } \\
\text { Ile } 7 \rightarrow \text { Asn } \\
\text { Agr } 47 \rightarrow H i s\end{array}$ & $\begin{array}{l}\text { Major/minor bands } \\
\text { Major/minor bands } \\
\text { Major/minor bands }\end{array}$ & $\begin{array}{l}\text { Single band } \\
1 \text { extra band } \\
1 \text { extra band }\end{array}$ \\
\hline 3 & 1433 & $\begin{array}{l}2 \\
2 \\
1 \\
1\end{array}$ & $\begin{array}{l}\text { Control } \\
\text { Insertion A: codon } 208 \\
\text { Arg129 } \rightarrow \mathrm{Gln} \\
\text { Asn } 187 \rightarrow \text { Lys }\end{array}$ & $\begin{array}{l}\text { Single band } \\
\text { Single band } \\
\text { Single band } \\
\text { Single band }\end{array}$ & $\begin{array}{l}\text { Single band } \\
\text { Single band } \star \\
\text { Single band } \\
\text { Single band }\end{array}$ \\
\hline $3 A$ & 385 & $\begin{array}{l}2 \\
1\end{array}$ & $\begin{array}{l}\text { Control } \\
\text { Arg129 } \rightarrow \text { Gln }\end{array}$ & $\begin{array}{l}\text { Single band } \\
\text { Single band }\end{array}$ & Single band \\
\hline $3 B$ & 262 & $\begin{array}{l}3 \\
2 \\
1\end{array}$ & $\begin{array}{l}\text { Control } \\
\text { Insertion A: codon } 208 \\
\text { Asn } 187 \rightarrow \text { Lys }\end{array}$ & $\begin{array}{l}\text { Single band } \\
\text { Single band } \\
\text { Single band }\end{array}$ & $\begin{array}{l}\text { Single band } \\
2 \text { extra bands } \\
2 \text { extra bands }\end{array}$ \\
\hline 4 & 515 & $\begin{array}{l}1 \\
1\end{array}$ & $\begin{array}{l}\text { Control } \\
\text { Glu237 } \rightarrow \text { Lys }\end{array}$ & $\begin{array}{l}\text { Single band } \\
\text { Single band }\end{array}$ & $\begin{array}{l}\text { Single band } \\
\text { Single band }\end{array}$ \\
\hline 5 & 230 & 2 & $\begin{array}{l}\text { Control } \\
\text { Insertion } G \text { : codon } 371\end{array}$ & $\begin{array}{l}\text { Single band } \\
\text { Single band }\end{array}$ & $\begin{array}{l}\text { Single band } \\
2 \text { extra bands }\end{array}$ \\
\hline 6 & 356 & $\begin{array}{l}2 \\
1 \\
1\end{array}$ & $\begin{array}{l}\text { Control } \\
\text { Ala382 } \rightarrow \text { Thr } \\
\text { Ala384 } \rightarrow \text { Ser }\end{array}$ & $\begin{array}{l}\text { Single band } \\
\text { Single band } \\
\text { Single band }\end{array}$ & $\begin{array}{l}\text { Single band } \\
1 \text { extra band } \\
1 \text { extra band }\end{array}$ \\
\hline
\end{tabular}

Italics indicate a positive result following electrophoresis in $100 \%$ Hydrolink gels

^Mutations detected by extended electrophoresis times (six hours). 